\title{
Positive matrix factorization on elemental concentrations of PM10 samples collected in areas within, proximal and far from mining and power station operations in Greece
}

\author{
Garas S.K. ${ }^{1 *}$, Triantafyllou A.G. ${ }^{1}$, Tolis E.I. ${ }^{2}$, Diamantopoulos Ch.N. ${ }^{1}$ and Bartzis J.G. ${ }^{2}$ \\ ${ }^{1}$ Laboratory of Atmospheric Pollution and Environmental Physics (LAP-EP), Department of Mineral Resources Engineering, University of \\ Western Macedonia, Kila, 50100, Kozani, Greece \\ 2Environmental Technology Laboratory, Department of Mechanical Engineering, University of Western Macedonia, Sialvera \& Bakola \\ Street, 50100, Kozani, Greece
}

Received: 11/04/2019, Accepted: 04/03/2020, Available online: 12/03/2020

*to whom all correspondence should be addressed: e-mail: stylgaras@gmail.com, www.airlab.edu.gr https://doi.org/10.30955/gnj.003128

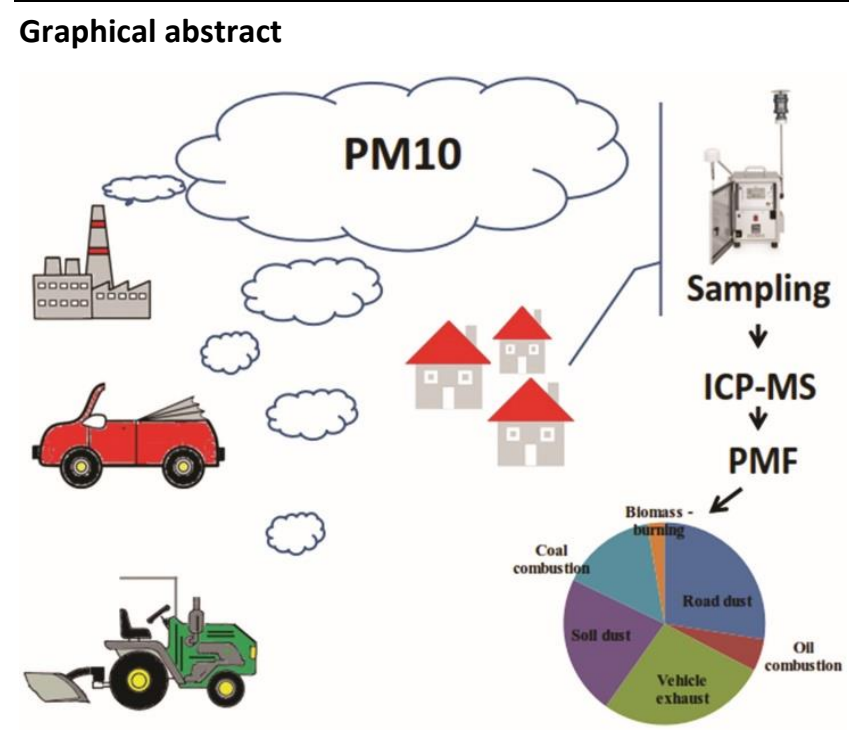

Abstract

The identification of PM sources and their contribution to measured PM concentrations is crucial for the environmental policy making since the findings be able to conduce to the development of relevant legislation in order to achieve effective air quality manage. In this study, the sources of PM10 at three receptors with different characteristics, within the Western Macedonia (WM) in NW Greece, were investigated: S1 in the center of Kozani, a medium sized city located at the southern edge of the industrial axis of WM, where urban activities and traffic density occur. S2 in the city of Ptolemaida, a medium sized city located in the centre of industrial zone, and S3 in the village of Eratyra, a rural residential district outside of the industrial area. For this purpose, the multivariate Positive Matrix Factorization (EPA PMF 5.0) receptor model was applied on elemental data. Specifically, PM10 samples, obtained by filtration during 1-year sampling campaign, were analyzed by ICP-MS instrument. Twenty-five elements were detected at quantifiable concentrations in the investigated PM samples. For the particle samples obtained in areas within and proximal from mining and power station operations, a six-factor model gave source profiles that attributed to be vehicle exhaust, road dust, soil dust, coal combustion, oil combustion and biomass burning. Furthermore, at the background site, the major contributors were biomass burning, soil dust and oil burning while no distant transport from industrial axis was recorded.

Keywords: PM10, elemental concentrations, positive matrix factorization, source profile.

\section{Introduction}

In general, airborne particles originate from several types of sources classified into two main categories natural (soil dust, marine aerosol, natural forest fires, volcanic activity...) and anthropogenic (industrial emissions, transportation, wood burning, consumption of fossil fuels...) and can be emitted directly or as secondary pollutant (Diapouli et al., 2017).

Due to their perilous effects on human health and the negative environmental effects, particulate matter emissions seem to be one of the most serious air quality problems for the people living in urban-industrial areas (Triantafyllou, 2001; WHO, 2003). In recent decades, suspended particles with a diameter smaller or equal to 10 $\mu \mathrm{m}$ (PM10) have attracted research interest and have been put "under the microscope". This results from the fact that these particles exhibit high penetration capability into the human respiratory system and easily trapped within the pulmonary alveoli. Many studies have brought to light a link between the ambient PM10 concentrations and their chemical composition with respiratory and cardiovascular ailments (Dockery and Pope, 1994; Schwartz et al., 1996; Cruz et al., 2015).

With a view to evolve a plan of action for efficient air quality control policy to implement the EU directive 
(2008/50/EC) it is of great importance to determine PM emission sources and estimate their contribution on atmospheric PM mass. Bearing that in mind, it is useful to be identified the elemental composition of ambient particulate matter (Manousakas et al., 2015).

Receptor modelling is an assessment technique that can give information for PM sources grounded on elemental composition data. Positive matrix factorization (PMF) is one of the multivariate statistic models that seem to have great applicability to many areas affected by various emission sources (Paatero and Tapper, 1994).

There are several investigations related to airborne particulate matter levels (Triantafyllou, 2001; Triantafyllou et al., 2006; Petaloti et al., 2006; Triantafyllou et al., 2007) but only three source apportionment studies (Samara, 2005; Samara et al., 2018; Tolis et al., 2014) for the area of Western Macedonia (W.M.), Greece. More specifically, Samara (2005) estimated the contribution of emission sources to Total Suspended Particles (TSP) using the Chemical Mass Balance (CMB) approach for Kozani, Ptolemaida and other eight urban and rural sites in the industrial basin of WM. In that research, the most significant sources were found to be diesel burning (as the major contributor at all sites), domestic coal burning, vegetative burning and refuse burning. Furthermore, the other study (Samara et al., 2018) carried out at four residential sites in the vicinity of lignite mining and combustion activities of the Western Macedonia Lignite Center (WMLC) by CMB model indicated vehicular traffic, biomass burning and mine operations as the most important PM10 emission sources. Correspondingly, Tolis et al. (2014) conducted source apportionment of ambient PM10 using 4-factor PMF technique but the number of PM samples was very limited, and these only concerned the city of Kozani. Nevertheless, their study indicated biomass combustion, traffic and lignite power plants emissions as the major atmospheric PM10 sources in Kozani.

The aim of the current work was: (1) to determine the atmospheric PM10 concentrations and their chemical composition, (2) to identify the possible emission sources and (3) to estimate their contribution to ambient PM10 values in areas within, proximal and far from mining and power station operations in WM, Greece. For this purpose, three different sampling sites were selected to investigate. In particular, two urban sites (Kozani, Ptolemaida) with specific features located in different distances from the industrial zone of Western Macedonia (W.M.), Greece, were chosen and one in a rural residential district (Eratyra). Additionally, the last one can be considered as a background sampling site since it is placed away from the industrial activities.

Ambient PM10 samples were analyzed by ICP-MS technique (Method 10-3.5, EPA). In total, twenty-five major, minor and trace elements were detected at quantifiable concentrations in the examined PM samples. Data obtained from one-year sampling/analysis campaign.

In order to determine the main PM10 source types and estimate their relative contribution the multivariate
Positive Matrix Factorization (PMF) receptor model was applied.

Note that in the present work, PM10 source apportionment study using the PMF model for the city of Ptolemaida (the most populated site in the centre of the WMLC) and for a residential site out of the industrial basin (Eratyra) carried out for the first time.

\section{Monitoring and modeling}

\subsection{Study area}

The industrial area of W. M. Greece extends along the axis of the provincial cities of Florina, Ptolemais and Kozani, from northwest to southeast direction (Figure 1). The main industrial activity takes place in a broad, relatively flatbottomed basin surrounded by mountains. In this zone four lignite power plants (LPPs) are operated by the Greek Public Power Corporation (GPPC). The LPPs use raw lignite as fuel that is mined in the nearby open-pit-mines and is transported in the power stations (PS) by trucks, wagons and conveyor belts. Large quantities of ash are emitted from stacks since the huge amount of lignite (about 64 Mt/year; Samara et al., 2018) is consumed. An additional significant source of particulates is the fugitive dust originated from mining activities (excavation, transport by trucks on unpaved roads, deposition of lignite and ash) and probably generated by resuspension due to strong winds (Triantafyllou et al., 2006). The climate of the area is continental Mediterranean characterized by low temperatures during winter and high ones during summer (Matthaios et al., 2013). From the data obtained by meteorological station (MS, $40.406^{\circ} \mathrm{N}$, $21.768^{\circ} \mathrm{E}$ and $702 \mathrm{~m}$ above sea level, Figure 1) for the period January 2008-December 2012 it results that the average daily winter temperature is $3.8^{\circ} \mathrm{C}$, the mean maximum daily winter temperature is $7.1^{\circ} \mathrm{C}$, and the mean minimum daily winter temperature is $0.8^{\circ} \mathrm{C}$. During the summer months these temperature values are 23.7, 29.4 and $17.9{ }^{\circ} \mathrm{C}$, respectively. For the same period, the prevailing winds in the industrial basin are weak to mediocre and mainly blow with NW/SE direction (Figure 2) due to channeling of the synoptic wind (Matthaios et al., 2018). Strong ground base nocturnal inversions are observed in the basin where the main industrial activity take place during the whole period of the year. The destruction of the nocturnal inversions is made early in the morning or late noon in relation to the season of the year following different patterns (Triantafyllou et al., 1995; Triantafyllou A.G., 2001).

Three receptor sites with different characteristics were chosen in order to investigate the PM10-bonded elements in samples of atmospheric particles:

S1 within the building tissue of Kozani $\left(40.299^{\circ} \mathrm{N}, 21.799^{\circ}\right.$ $\mathrm{E}, 711 \mathrm{~m}$ above sea level), where urban activities and traffic density occur. Kozani is the major city in Western Macedonia, Greece $(50,000$ inhabitants) located at the southern edge of the industrial zone about 13, 43, $56 \mathrm{~km}$ (S) and $14 \mathrm{~km}(\mathrm{SW})$ to the lignite power plants PS3, PS2, PS1 and PS4, respectively and about $11-35 \mathrm{~km} \mathrm{~S}$ to the 
opencast lignite mines South Field, Kardia, Mavropigi and Amyntaio (Figure 1).

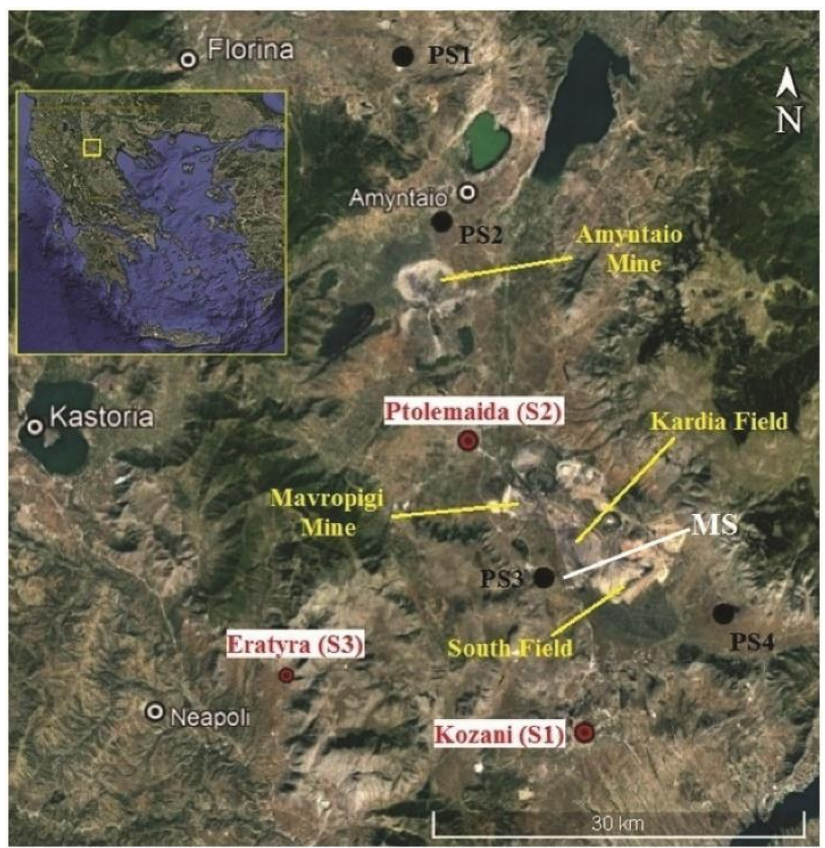

Figure 1. Map showing the lignite power stations (PS) and the opencast lignite mines in Western Macedonia, Greece. Receptor sites Kozani (S1), Ptolemaida (S2) and Eratyra (S3) are also shown. (MS: meteorological station)

$\mathrm{S} 2$ in the city of Ptolemaida $\left(40.513^{\circ} \mathrm{N}, 21.677^{\circ} \mathrm{E}\right.$ and 610 $\mathrm{m}$ asl), the second most populated city of the area $(32,000$ inhabitants), which is located in the centre of the industrial area with opencast coal mining and lignite combustion activities. More specifically, Ptolemaida is located about 31 $\mathrm{km}(\mathrm{S}), 17 \mathrm{~km}(\mathrm{~S}), 13 \mathrm{~km}(\mathrm{~N})$ and $25 \mathrm{~km}(\mathrm{NW})$ to the lignite power plants PS1, PS2, PS3 and PS4, respectively. Furthermore, the city is surrounded by four opencast lignite mine, namely the South Field (in a distance of $17 \mathrm{~km}$ SE), Kardia (12 km SSE), Mavropigi (6 km SSE) and Amyntaio (12 km N) (Figure 1).

S3 in Eratyra $\left(40.341^{\circ} \mathrm{N}, 21.511^{\circ} \mathrm{E}\right.$ and $740 \mathrm{~m}$ asl), a village in a rural residential district, with 1,400 inhabitants (Figure 1 ). It is located on the south, south-west sector, in a distance of about 21-51 km away from the mining and power station operations, outside of the basin where the main industrial activity occurs. In addition, it must be mentioned that the Askio Mountain (with an altitude of about $2000 \mathrm{~m}$ ) is interposed between the village and the industrialized zone. So, since it is not directly influenced by industrial emissions it is considered as a background station.

\subsection{Ambient sampling}

The sampling campaign was carried out in the course of a year at three receptors S1 (08/2015 to 07/2016), S2 and S3 $(11 / 2013$ to $10 / 2014)$. Samples were collected on PTFE membrane filters (teflo, Pall) using low volume air samplers equipped with PM10-selective head (PM162M Environnement S.A. and Derenda LVS) while each sampling lasted twenty-four hours starting at midnight. Loaded and unloaded filters were weighted after being exposed for 48 $\mathrm{h}$ in an air-conditioned weighing room at constant temperature $\left(23-25^{\circ} \mathrm{C}\right)$ and relative humidity (40-50\%) for the gravimetric determination of the particle mass concentration.

Finally, 64, 163 and 62 PM10 samples were obtained at three receptor sites Kozani (S1), Ptolemaida (S2) and Eratyra (S3) respectively.

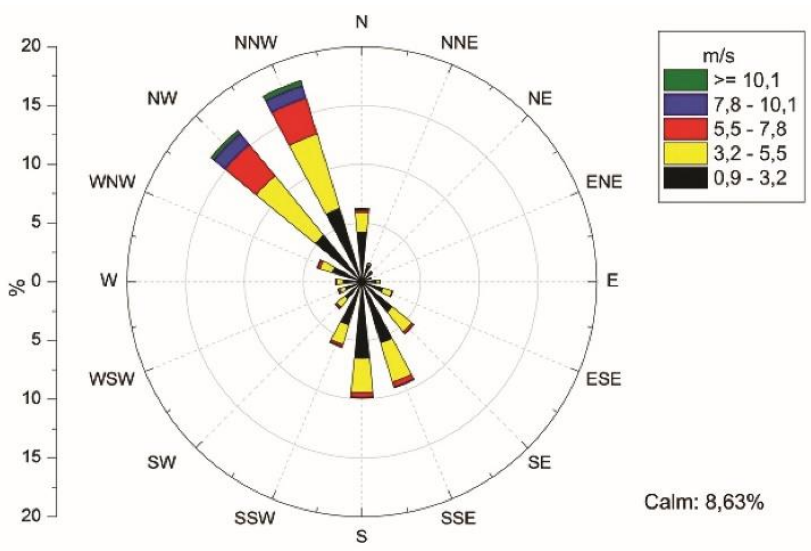

Figure 2. Wind rose (2008-2012). The frequency of calms is also indicated

\subsection{Elemental analysis}

A cross-section of the PM10 samples, for each receptor, underwent an elemental analysis in order to define major, minor and trace elements in the atmospheric particles. In particular, 33, 44 and 21 filters were analysed for S1, S2 and S3 sampling site respectively. The selection of samples to be analyzed was carried out taking into account the seasonality and the variability of meteorological conditions and so can be considered representative for whole sampling period. It must be noted that the samples corresponding to Sahara Dust events were excluded.

Inductively coupled plasma mass spectrometry (ICP-MS) was used for the determination of $\mathrm{Be}, \mathrm{Na}, \mathrm{Mg}, \mathrm{Al}, \mathrm{K}, \mathrm{Ca}, \mathrm{V}$, $\mathrm{Cr}, \mathrm{Mn}, \mathrm{Fe}, \mathrm{Ni}, \mathrm{Co}, \mathrm{Cu}, \mathrm{Zn}$, As, Se, Mo, Ag, Cd, Sb, Ba, Tl, Pb, Th and $U$ in suspended particles with a diameter smaller or equal to $10 \mu \mathrm{m}$.

Loaded filters were extracted by hot acid procedure (Method IO-3.1, EPA) with $8 \mathrm{~mL}$ mixed acid (1:3 ratio of high purity $\mathrm{HNO}_{3}$ and $\mathrm{HCl}$ ). All the extracts were filtered through $0.45 \mu \mathrm{m}$ membrane filter and were diluted to $25 \mathrm{~mL}$ with high purity water. Eventually, the resulted aqueous solutions were analysed using ICP-MS (Agilent 7500) according to analytical procedures reported by the instrument manufacturer. The extraction procedure and the analytical method have been described in Garas et al. (2017).

The final elemental concentrations presented here have been properly corrected using the recovery rates and blank filters. 


\subsection{Positive matrix factorization}

Positive Matrix Factorization (PMF) is an advanced receptor model developed by Paatero and Tapper (1993), with the purpose of evolving a modern multivariate factor analysis technique. PMF can be used in soils, wastewater, air quality and source apportionment studies (Comero et al., 2009).

The main characteristics of PMF are the weighing of data points using their experimental uncertainties and the ability to manage missing data and outliers. Furthermore, the objective of multivariate Positive Matrix Factorization receptor modeling is to specify the total number of factors (PM10 emission sources) $p$, the profile (elemental composition) of each source and the contribution of the $p$ factors to each atmospheric PM10 sample (Comero et al., 2009). The PMF model can be described with the general equation (Eq. 1):

$$
\begin{aligned}
& X=G F+E \\
& Q(E)=\sum_{i=1}^{m} \sum_{j=1}^{n}\left(e_{i j} / s_{i j}\right)^{2}
\end{aligned}
$$

$X$ is an $(n \times m)$ data matrix consisting of the concentrations of $n$ chemical species in m PM10 samples, $G$ is an $(n \times p)$ matrix of emission source profiles and $F$ is a $(p \times m)$ matrix of factor contributions to the samples. Moreover, $\mathrm{G}$ depicts the temporal variation of the emission sources while $E$ represents the unmodeled by the $\mathrm{p}$-factor model data (residual matrix). The objective of PMF is minimizing the $Q$ value described (Eq. 2) as the sum of square of the residuals ( $\left.e_{i j}\right)$ weighted inversely with uncertainties $\left(s_{i j}\right)$ of the measured elemental mass concentrations.

\section{Results and discussion}

\subsection{PM10 concentrations}

The mean annual PM10 concentrations measured at Kozani and Eratyra were 29 and $18 \mu \mathrm{g} \mathrm{m}^{-3}$ respectively and were below the annual limit of $40 \mu \mathrm{g} \mathrm{m}^{-3}$ that is proposed by the EU (83/399/ECC). On the contrary, the mean annual value at the third receptor site S2 (Ptolemaida) was $40 \mu \mathrm{g} \mathrm{m}^{-3}$, equal to the current standard.

The percentage of daily PM10 concentrations that were higher than the $24 \mathrm{~h}$ limit value of $50 \mu \mathrm{g} \mathrm{m} \mathrm{m}^{-3}$ ranged between $0 \%$ and $28.2 \%$, across the three sites with the highest value being recorded at Ptolemaida. In particular, 46 mean daily values (28.2\% of PM10 values) in 163 samples, exceeded the daily limit value $\left(50 \mu \mathrm{g} \mathrm{m}^{-3}\right.$, not to be exceeded over 35 times in a year, EC, 1999). These results are lower than those referred in literature for urban-industrial sites in South, Central and Eastern Europe (D. Voutsa et al., 2002; X. Querol et al., 2002; Jannsen et al., 1997; Houthuijs et al., 2001) but slightly higher than those reported for North and Western Europe (Lazaridis et al., 2002). In the case of Kozani, 4 exceedances (6.2\%) in 64 cases were observed. These findings are significantly lower than those previous reported regarding the same area for the years 1991-1994 (Triantafyllou, A.G., 2001). This might be attributed to antipollution actions of GPPC
(Triantafyllou et al., 2006) and/or -more likely- to operation of the installed district heating system. It should be noted that, since 1993, a district heating (also known as heat network or teleheating) system has been installed and is available in most households of Kozani. This heating system distributes heat, through isolated pipes, generated in a remote location for residential and commercial heating requirements. In the present case the heat is obtained from nearby power plants burning coal. However, no value recorded on a 24-hour basis exceeded the daily limit in the S3 background station at the village of Eratyra.

\subsection{Elemental concentrations}

PM10 chemical composition at the three receptor sites is presented in Figure 3. The summed mass of the 25 elements that were determined in this study corresponded in $12.5,12.6$ and $5.9 \%$ of the PM10 mass for S1, S2 and S3 receptor sites respectively.

Crustal matter ( $\mathrm{Al}, \mathrm{Ca}, \mathrm{Mg}$, Fe), was the main component of $\mathrm{PM} 10$ (Figure 4). The concentrations of $\mathrm{Ca}, \mathrm{Fe}, \mathrm{Mg}, \mathrm{Al}, \mathrm{Na}$, $\mathrm{K}, \mathrm{Mn}, \mathrm{Co}, \mathrm{As}, \mathrm{Cd}$ and $\mathrm{Pb}$ were relatively higher at the S2 receptor site which is located, as it is mentioned above, close to the opencast coal mining and lignite power plants and it is directly affected by industrial emissions. It must be noted that the major elements ( $\mathrm{Ca}, \mathrm{Fe}, \mathrm{Mg}, \mathrm{Al}, \mathrm{Na}, \mathrm{K}$ ) are mainly originated from crustal source (Lopez et al., 2005), while, at the same time, these elements are the main components of coal fly ash (US EPA, 1999; Samara C., 2005). Regarding the trace elements ( $\mathrm{Mn}, \mathrm{Co}, \mathrm{As}, \mathrm{Cd}$ and $\mathrm{Pb}$ ) are known to arise at high temperatures during the combustion of coal (Izquierdo and Querol, 2012). At all three sites the mean lead concentrations were well below the ambient air quality standard of $500 \mathrm{ng} \mathrm{m}^{-3}$ (as annual mean, EC, 1999). The mean values of $\mathrm{As}, \mathrm{Cd}$ and Ni were also lower than the proposed assessment thresholds $(6,5$ and $20 \mathrm{ng} \mathrm{m}^{-3}$, respectively, EC, 2003). In the case of $\mathrm{V}$, the proposed $24 \mathrm{~h}$ concentration limit value of $1 \mu \mathrm{g} / \mathrm{m}^{3}$ (WHO, 2000) never exceeded during the sampling campaign. Finally, the mean total concentration of $\mathrm{Mn}$ was lower than the annual tolerance concentration included in the WHO Air Quality Guidelines (150 ng m $\mathrm{m}^{-3}$, WHO, 2000).
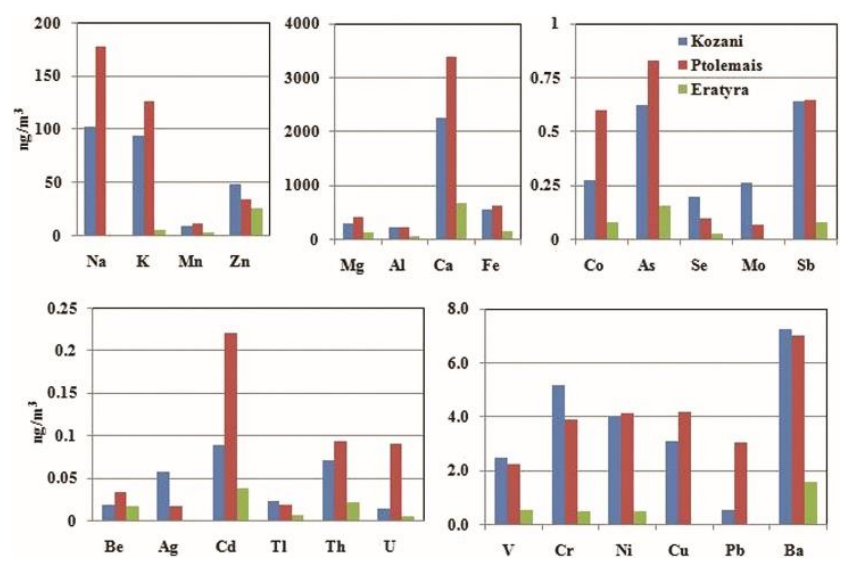

Figure 3. Ambient PM10 profiles at receptor sites Kozani (S1), Ptolemaida (S2) and Eratyra (S3) 


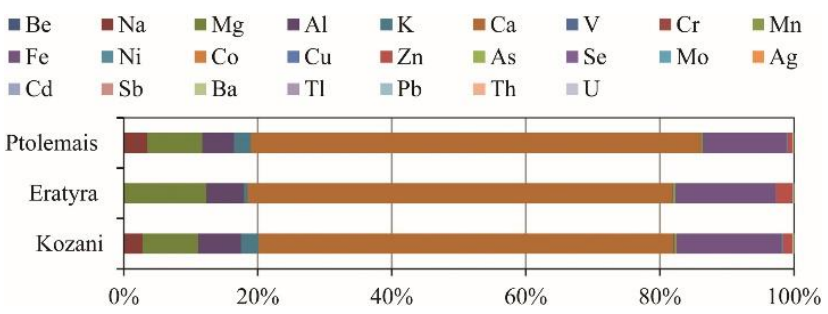

Figure 4. Mean elemental composition of ambient PM10

\subsection{Determination of the number of sources}

Generally, receptor models permit to extract information on emission sources number, composition and contribution to air pollutant concentration at receptor site.

For this purpose, the multivariate Positive Matrix Factorization (PMF) receptor model was applied and an attempt was made to identify the main ambient PM10 sources that affect the sampling sites.

In PMF, the selection for the input data is crucial and based on analytical sensitivity, accuracy, and detection limit. Due to the fact that the measured sum of elements is a small part of gravimetrically measured atmospheric PM10 mass since it fluctuated from 5.9 to $12.6 \%$ at three sampling sites, the ambient PM10 concentration time series purvey addable information to PMF receptor model (Gupta et al., 2012). Consequently, particle matter with an aerodynamic diameter less or equal to $10 \mu \mathrm{m}$ is considered as a distinct species and so, it participates in the input data matrixes. Eventually, in order to carry out analyzes on PM10 sources, data matrixes with dimensions of $33 \times 26,44 \times 26$ and $21 \times$ 26 for S1, S2 and S3 receptor sites were prepared with 25 metal elements in addition to PM10 mass concentrations. The data less than detection limit, were replaced with a half value of detection limit for each element and their error estimates were used for $5 / 6$ of those detection limits (Polissar et al., 1998). The species to be included in the PMF analysis were selected using the signal to noise $(\mathrm{S} / \mathrm{N})$ ratio. A variable is called "weak" if the $S / N$ ratio is between 0.9 and 4 . Species with $S / N$ ratio less than 0.9 are denoted as "bad" variables and are excluded from the analysis.

A basic step in PMF analysis is the determination of the number of factors. Analysis of the goodness of model fit, $Q$, as defined in Eq. 2, can be used to help determine the optimal number of factors. $Q_{\text {robust }}$ is calculated excluding outliers and the $Q_{\text {true }}$ is calculated including all points. Solutions where $Q_{\text {true }}$ is greater than 1.5 times of $Q_{\text {robust }}$ indicate that peak events may be disproportionately influencing the model (Gupta et al., 2012). It must be noticed that the base model run with the lowest $Q_{\text {robust }}$ was automatically selected by the program for $F_{\text {peak }}$ runs. The $F_{\text {peak }}$ parameter was used to refine the source profiles, and there were no significant differences than those obtained with zero $F_{\text {peak }}$ value.

A tool for selecting the optimal number of factors based on the expected $Q\left(Q_{\exp }\right)$ value (Bzdusek et al., 2006), which is given by (Paatero and Tapper, 1993; Eq. 3):

$$
Q_{\exp }=(n-p) \times(m-p)
$$

It must be noticed that the $Q_{\exp }$ value gives important information about the quality of the fit since the optimal solution should have a $Q$ not too different from the $Q_{\exp }$ value.

Datasets of receptor sites Kozani (S1), Ptolemaida (S2) and Eratyra (S3), from 3 to 8 factors were tested (with FPEAK = $0)$ and the resulting $Q_{\text {true }} / Q_{\exp }$ values were plotted (Figure5):


Figure 5. $Q_{\text {true }} / Q_{\text {exp }}$ values from different number of factors for receptor sites (a) Kozani (S1), (b) Ptolemaida (S2) and (c) Eratyra

The $Q_{\text {true }} / Q_{\text {exp }}$ values steadily decrease except from factor 3 to 4,3 to 5 and 2 to 3 for S1, S2 and S3 receptor site respectively, where the slopes are greater. This suggests that the solutions with 3, 3 and 4 and 2 factors respectively, should be rejected.

In Positive Matrix Factorization, the selection of the number of factors is subjective. Using a maximum number of factors will create unrealistic sources without physical sense. On the other hand, using very few factors there is a risk to combine different sources together. 

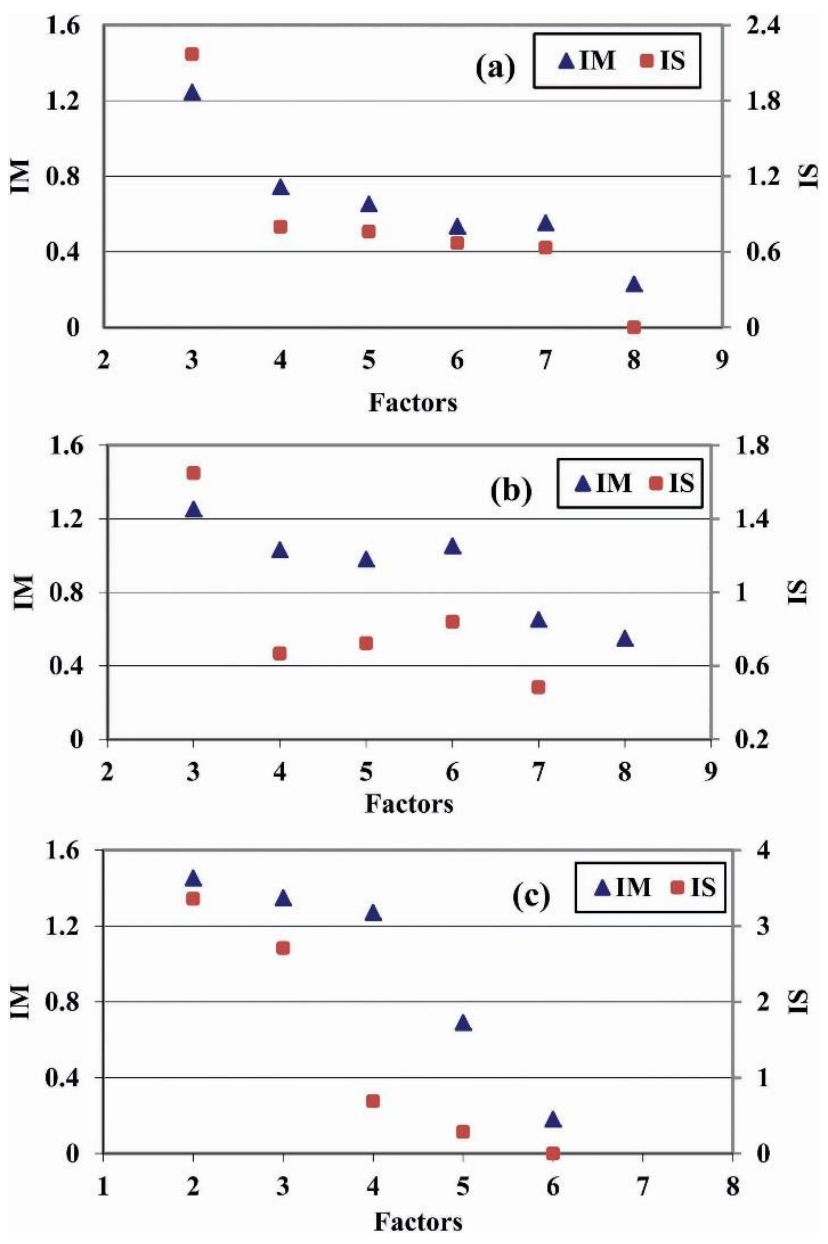

Figure 6. IM and IS plot vs number of factors for receptor sites (a) Kozani (S1), (b) Ptolemaida (S2) and (c) Eratyra (S3)

In order to reduce the range of the optimal number of factors, the maximum individual column mean (IM) and the maximum individual column standard deviation (IS), were used (Lee et al., 1999). Starting from the scaled residual matrix $R$, these parameters are defined as follow:

$$
\begin{aligned}
& I M=\max _{j=1 . . . m}\left(\frac{1}{n} \sum_{i=1}^{n} r_{i j}\right) \\
& I S=\max _{j=1 . . m}\left(\sqrt{\frac{1}{n-1} \sum_{i=1}^{n}\left(r_{i j}-\bar{r}_{j}\right)^{2}}\right)
\end{aligned}
$$

Where $r_{i j}=\left(e_{i j} / s_{i j}\right)$ is each element in matrix $\mathrm{R}$ and $\bar{r}_{j}$ the mean over the ith row.

As stated, IM represents the jth variable with greater scaled residuals mean and so the less accurate one. Instead IS reproduces the jth variable with greater scaled residual standard deviation and so the more imprecise fit. Plotting these parameters against the number of factors it is possible to reject some of them. When the number of factors approaches to a critical value, IM and IS show a drastic decrease. As shown in Figure 6a,b, analyzing IM values from the S1 and S2 receptor sites data-sets, was observed a rapid decrease of IM from 3 to 4 number of factors and a further decrease from 7 to 8 and from 6 to 7 for Kozani and Ptolemaida respectively. On the contrary, the IS graphs (Figure 6a, b and c) show a first step between 4 and 5 number of factors. From all the above analyzes it seems that solutions with 4 or more (for S1 and S2) and 3 or more (for S3) number of factors have a better fit.

Finally, knowledge of the possible sources in the receptor sites (S1, S2 and S3) can provide an answer on choosing the most optimal number of factors between 3 and 7 . Therefore, the 6, 6 and 3-factor model was used to analyze data-sets and identify the main PM10 sources that affect the sampling sites at Kozani, Ptolemaida and Eratyra, respectively.

\subsection{Source identification}

The characterization of specific particle sources is particularly challenging due to a large number of urban and industrial sources presenting similar elemental profiles (Lee et al., 1999; Kim et al., 2007; Watson et al., 2004). Despite the fact that the trace elements participate in small quantities in the total particulate mass, they play a crucial role in the classification of the sources that affect the receptor sites. The identification of sources was conducted using major marker species that can be estimated based on number of references.

\subsubsection{The case of Kozani (S1)}

A total of six factors (sources) were obtained for the sampling site at city of Kozani. More specifically, two traffic sources (Road dust and Vehicle exhaust), Soil dust, Biomass burning, Coal and oil combustion were identified. The PMF factor profiles for Kozani are given in Figure 7. Furthermore, the pie-chart in figure 8 presents the average source contribution for the sampling period.

The coefficient of determination between predicted PM10 concentrations from all sources and the observed PM10 concentrations was 0.80 . This proves that the identified factors reproduce with fairly high precision the measured PM10 concentrations.

The first factor was dominated by $\mathrm{Mg}(26 \%), \mathrm{Ca}(25 \%), \mathrm{Cu}$ $(23 \%), \mathrm{Fe}(13 \%), \mathrm{Sb}(27 \%)$ and $\mathrm{Ba}(20 \%)$. This source is estimated to be road dust and was traced by elements that come from brake, tire and vehicle body wear ( $\mathrm{Cu}, \mathrm{Fe}, \mathrm{Zn}$ ) (Diapouli et al., 2017; Schauer et al., 2006), while it also contained crustal metals from road-surfacing material wear $(\mathrm{Mg}, \mathrm{Ca}, \mathrm{Fe})$ which are resuspended by vehicular traffic (Diapouli et al., 2017). Other elements contributing to the road dust profiles were $\mathrm{Sb}$ and Ba which can be used as the major marker species (Pakkanen et al., 2001). According to the literature, $\mathrm{Ba}$ is an additive and may be emitted from the combustion of lubricating oil (Monaci and Bagagli, 1987). The contribution of this factor was $27.5 \%$ of PM10 mass on an average $7.5 \mu \mathrm{g} \mathrm{m}^{-3}$ at S1 receptor site.

The second source is assumed to be the oil combustion. This factor was dominated by $\mathrm{Cr}(50.3 \%), \mathrm{Zn}$ (33.1\%), V (37.1\%) and As (24.9\%). Cr originates from coal and oil combustion, at high temperatures (Lim et al., 2010; Uberoi and Shadman, 1991) while $V$ comes from oil combustion (Vallius et al., 2005) used in the power stations to start up generators (27000 tonesy ${ }^{-1}$; Kalaitzoglou et al., 2014) and constitutes a typical indicator for this process. $\mathrm{Zn}$ and As 
are assigned as marker species for coal combustion (Lee et al., 2002; Morishita et al., 2006; Chueinta et al., 2000). The identification of $\mathrm{Zn}$, As and $\mathrm{V}$ in the particular factor, indicates combined use of coal and oil combustion. This source (oil - start up fuel combustion) constitutes about $5.1 \%$ of PM10 during the whole period.

The next factor was dominated by Sb (35.2\%), Pb (32.2\%) and $\mathrm{Zn}(27.5 \%)$. This emission source is estimated to be vehicle exhaust. $\mathrm{Zn}$ may be contributed from galvanized materials and tire wear (Diapouli et al., 2017; Santoso et al., 2008) and may be also originated from the combustion of lubricating oil (Viana et al., 2008). Pb comes from a variety of emission sources, traffic and tire wear, incineration, fossil fuel combustion, etc (Smichowski et al.,, 2008). Pb used to be one of the trace elements considered as a marker of vehicle traffic for years. However, with the implementation of legislation on the use of unleaded fuel in Europe (EC, 1998), gasoline is not a dominant pollution source of $\mathrm{Pb}$. Huang et al. (1994) assigned $\mathrm{Sb}$ and $\mathrm{Br}$ as markers for vehicular exhaust. Vehicle exhaust factor constitutes about $27.2 \%$ of PM10 during the sampling period with an average of $7.4 \mu \mathrm{g} \mathrm{m}^{-3}$.

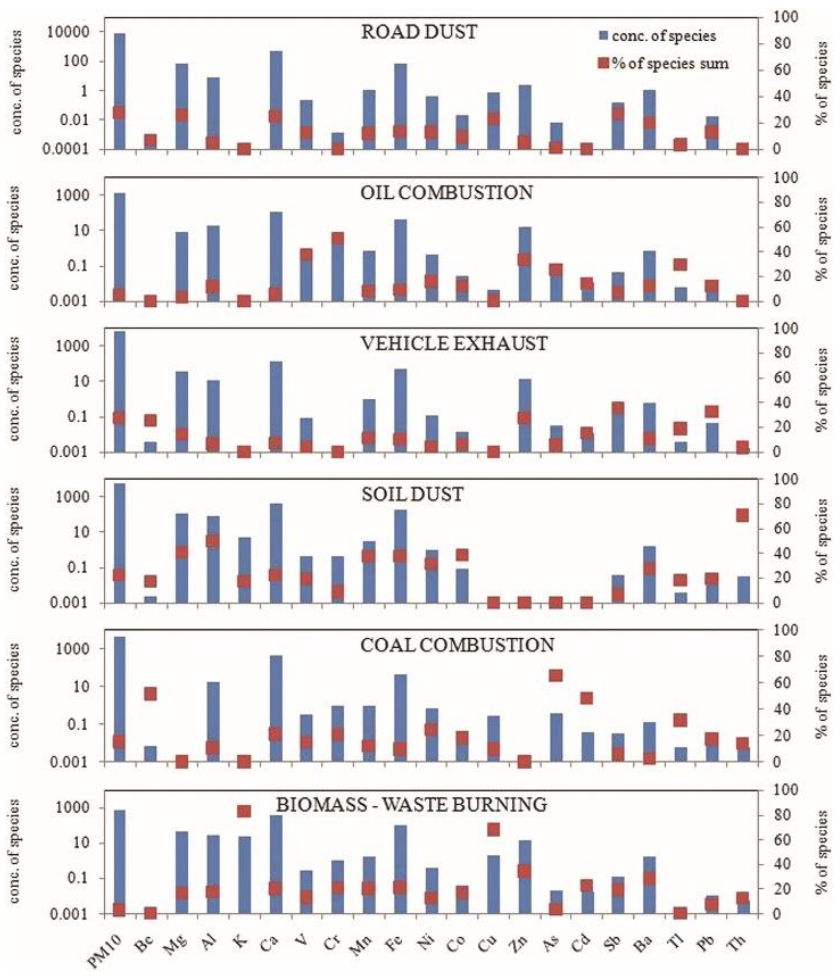

Figure 7. PMF factor profile forKozani (S1)

The fourth source is typical soil dust including natural windblown dust from surrounding regions and fugitive dust emissions from agricultural and mining activities. This factor is represented by elements $\mathrm{Al}$ (49.7\%), $\mathrm{Mg}$ (40.6\%), Ca (22.3\%), Mn (37.6\%), Fe (37.3\%), Ni (31.0\%), Co (38.1\%), Ba (27.4\%) and Th (70.5 \%) which are mainly originated from crustal source (Lopez et al., 2005). Soil dust constitutes about $22.3 \%$ of the PM10 during the whole period with an average of $6.1 \mathrm{\mu g} \mathrm{m}^{-3}$.

The fifth factor is characterized by the presence of Be $(51.2$ \%), Ca (20.8\%), Cr (20.4\%), Ni (24.4\%), As (64.9\%), Cd
(47.9 \%), $\mathrm{Pb}(17.0 \%)$ and $\mathrm{TI}(31.4 \%)$. It was identified as a coal combustion process. It should be noted that in the northern sector of Kozani, four lignite power stations are established and operated by the Greek Public Power Corporation. Calcium originates from lignite combustion since it is existing in fly ash, mainly as lime, anhydrite, calcite etc. and of course constitutes the most largely released element (Izquierdo and Querol, 2012). Trace elements $\mathrm{Be}, \mathrm{Cr}, \mathrm{Ni}, \mathrm{As}, \mathrm{Cd}, \mathrm{Pb}$ and $\mathrm{Tl}$ are known to arise at high temperatures during the combustion of coal (Izquierdo and Querol, 2012). In accordance to literature (Chueinta et al., 2000), As is widely used as a marker for coal combustion. This source constitutes about $15.2 \%$ of PM10 during the whole sampling period with an average of $4.1 \mu \mathrm{g} \mathrm{m}^{-3}$.

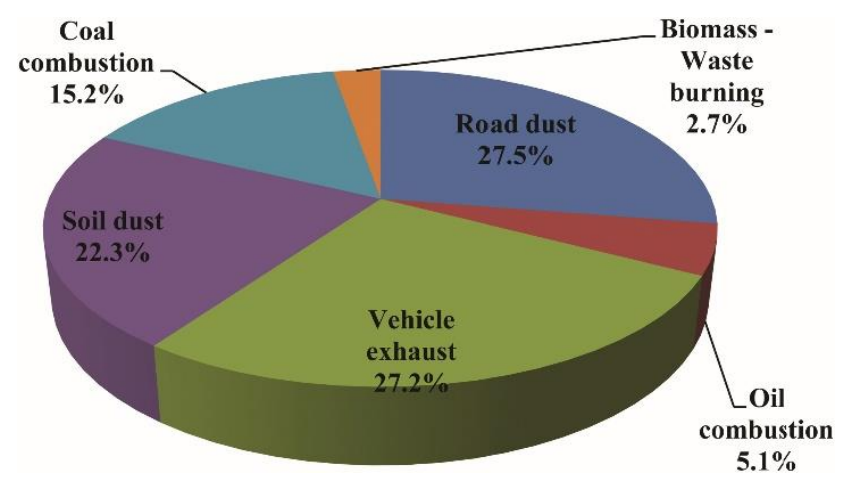

Figure 8. Source contribution for receptor site of Kozani (S1)

The sixth source was assigned to biomass burning by considering the high percentage of $\mathrm{K}(82.7 \%)$. Wood combustion for residential heating and vegetation burning (field burning) emissions are potential sources. $67.8 \%$ of $\mathrm{Cu}$ and $34.3 \%$ of $\mathrm{Zn}$ were also present in this factor, which are tracers for waste burning (Bruin et al., 2006). The PMF model could not discern between these two sources. The contribution of biomass - waste burning was $2.7 \%$ of PM10 mass on an average of $0.7 \mu \mathrm{g} \mathrm{m}^{-3}$.

\subsubsection{The case of Ptolemaida (S2)}

Optimal number of sources (factors) chosen was six. More specifically, Road dust, Vehicle exhaust, Oil burning, Biomass burning, Soil dust and Coal combustion were identified. The PMF factor profiles for Ptolemaida are given in Figure 9. Furthermore, the pie-chart in Figure 10 presents the average source contribution for the sampling period. The $r^{2}$ of determination between predicted PM10 concentrations from all sources and the observed PM10 concentrations was 0.86 .

The first factor was dominated by $\mathrm{Mg}(47.4 \%)$, $\mathrm{Al}$ (44.6\%), $\mathrm{Mn}(44.1 \%), \mathrm{Fe}(43.5 \%), \mathrm{Ni}(40.2 \%), \mathrm{Co}(40.4 \%), \mathrm{Zn}(29.5 \%)$, $\mathrm{Ba}(35.6 \%), \mathrm{Tl}(46.9 \%)$ and $\mathrm{Th}(49.6 \%)$. This source is estimated to be road dust. This factor was traced by elements (Fe, $\mathrm{Zn}$ ) that originate from vehicle body, brake and tire wear (Diapouli et al., 2017; Schauer et al., 2006), while it also comprised metals (Al, Mg, Mn, Fe, Ni, Co and Th) which are mainly come from crustal emission source (Lopez et al., 2005). It should be noted that road dust is a source of particles accumulated on the road surface, which 
are emitted by resuspension due to vehicular traffic. Other element contributing to the road dust profile was Ba which can be used as the major marker (Pakkanen et al., 2001). The contribution of road dust was $13.9 \%$ of PM10 mass on an average of $4.6 \mathrm{\mu g} \mathrm{m}^{-3}$.

The second source is assumed to be the oil combustion. This factor was dominated by $\mathrm{V}(50.8 \%), \mathrm{Cr}(44.7 \%)$ and $\mathrm{Zn}$ (47.5\%). V comes from oil combustion (Vallius et al., 2005) in Lignite Power Stations during their ignition and constitutes a typical indicator for this process. $\mathrm{Cr}$ originates from coal and oil combustion, at high temperatures (Lim et al., 2010) while $\mathrm{Zn}$ is assigned as a marker for coal combustion (Lee et al., 2002; Morishita et al., 2006; Chueinta et al., 2000). The identification of V, $\mathrm{Cr}$ and $\mathrm{Zn}$ in the particular factor indicates combined use of oil and coal as a start up fuel at the Power Plants. This source constitutes about $9.9 \%$ of PM10 during the whole period on an average of $3.3 \mu \mathrm{g} \mathrm{m}^{-3}$.

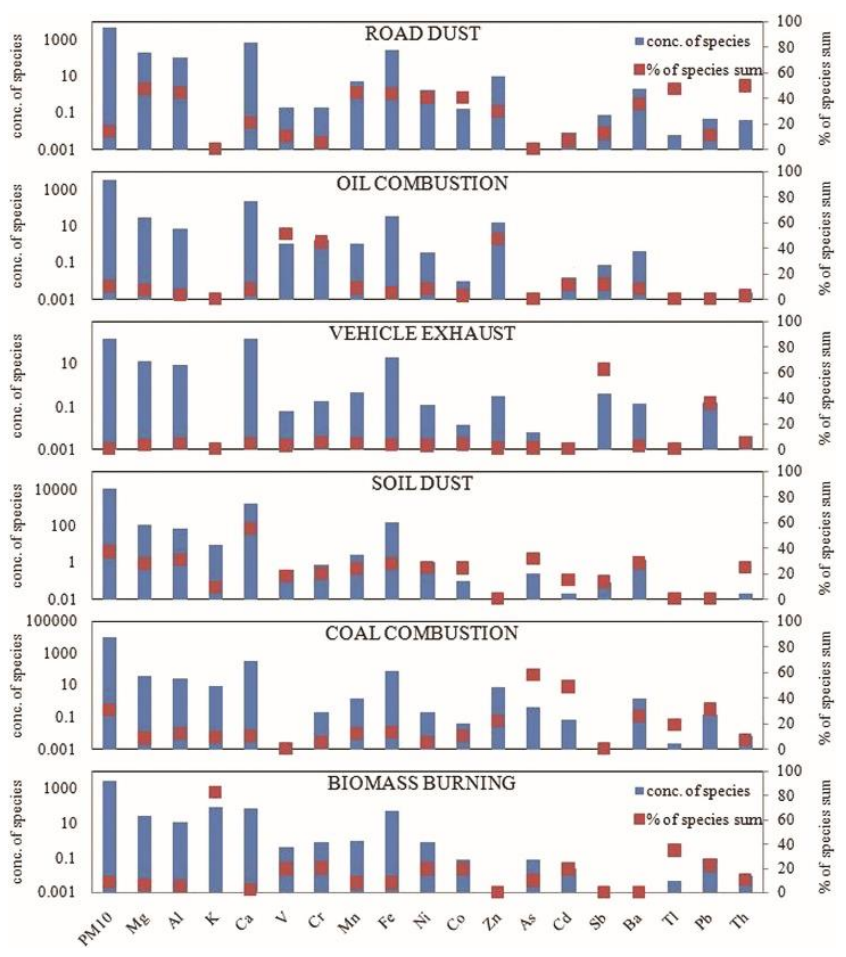

Figure 9. PMF factor profile for Ptolemaida (S2)

The next factor was dominated by $\mathrm{Sb}(62.2 \%)$ and $\mathrm{Pb}(35.8$ $\%)$. This emission source is estimated to be vehicle exhaust. $\mathrm{Pb}$ originates from a variety of pollution emissions, traffic and tire wear, fossil fuel combustion, etc. Sb is assigned as a marker for vehicular exhaust. This factor constitutes about $0.5 \%$ of PM10 during the sampling period.

The fourth factor is represented by elements Al (30.9\%), $\mathrm{Mg}(27.5 \%), \mathrm{Ca}(55.1 \%), \mathrm{Mn}(23.5 \%)$, Fe (27.4\%), Ni (24.4 $\%)$, Co $(24.1 \%)$, Ba $(28.0 \%)$ and Th (24.8\%) which are mainly originated from crustal source (Lopez et al., 2005). The identification of $\mathrm{As}(31.3 \%)$ and $\mathrm{Cd}(14.8 \%)$ in the particular factor, indicates participation of fly ash in the particle matter. This source is estimated to be Soil dust including natural windblown dust from surrounding regions and fugitive dust emissions from mining activities such as operation of mining equipment, translocation of soil or coal, vehicle traffic on unpaved roads, transportation and deposition of lignite and lignite ash. Soil dust constitutes about $36.9 \%$ of the PM10 during the whole period with an average of $12.3 \mathrm{\mu g} \mathrm{m}^{-3}$.

The fifth factor is characterized by the presence of As (58.2 $\%), \mathrm{Cd}(48.5 \%)$ and $\mathrm{Pb}(30.9 \%)$. It was identified as a coal combustion process. Trace elements $\mathrm{As}, \mathrm{Cd}$ and $\mathrm{Pb}$ are known to arise at high temperatures during the combustion of coal (Izquierdo and Querol, 2012) while As is used as a marker for coal combustion (Chueinta et al., 2000). This source constitutes about $30.8 \%$ of PM10 during the whole sampling period with an average of $10.2 \mathrm{\mu g} \mathrm{m}^{-3}$.

The sixth factor was assigned to biomass burning. This source was dominated by $\mathrm{K}$ (82.1 \%). Wood combustion for residential heating and vegetation burning emissions are potential sources. It must be noted that during the sampling campaign the biomass was used as fuel (mixture $8 \%$ of dried cultivated plants in coal; unofficial data by the GPPC) in the Power Station of Kardia (PS3, Figure 1). The contribution of this factor was $8.1 \%$ of PM10 mass on an average of $2.7 \mu \mathrm{g} \mathrm{m}^{-3}$.

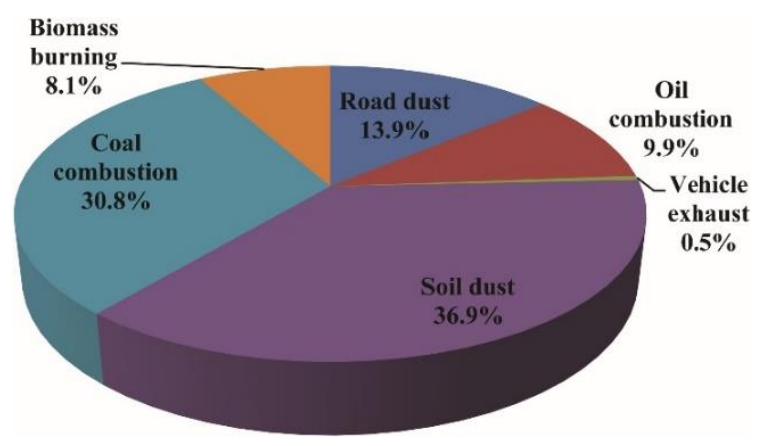

Figure 10. Source contribution for receptor site of Ptolemaida (S2)

\subsubsection{The case of Eratyra (S3)}

A total of three sources were obtained for the sampling site (S3) at village of Eratyra. More specifically, Biomass burning, Soil dust, and Oil combustion were identified. The PMF factor profiles for Eratyra are given in Figure 11. Furthermore, the pie-chart in Figure 12 presents the average source contribution. The $r^{2}$ of determination between predicted PM10 concentrations from all sources and the observed PM10 concentrations was 0.91 .

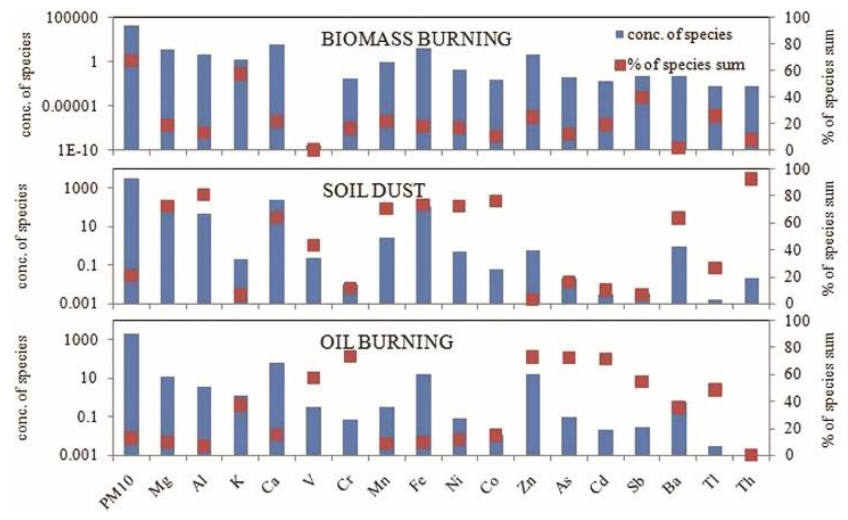

Figure 11. PMF factor profile for Eratyra (S3) 
The first factor is characterized by the presence of high percentage of $\mathrm{K}(57.1 \%)$. This source was assigned to biomass burning, including Wood combustion for residential heating and vegetation burning (field burning), emissions. The contribution of biomass was $67.2 \%$ of PM10 mass on an average of $11.8 \mu \mathrm{g} \mathrm{m}^{-3}$.

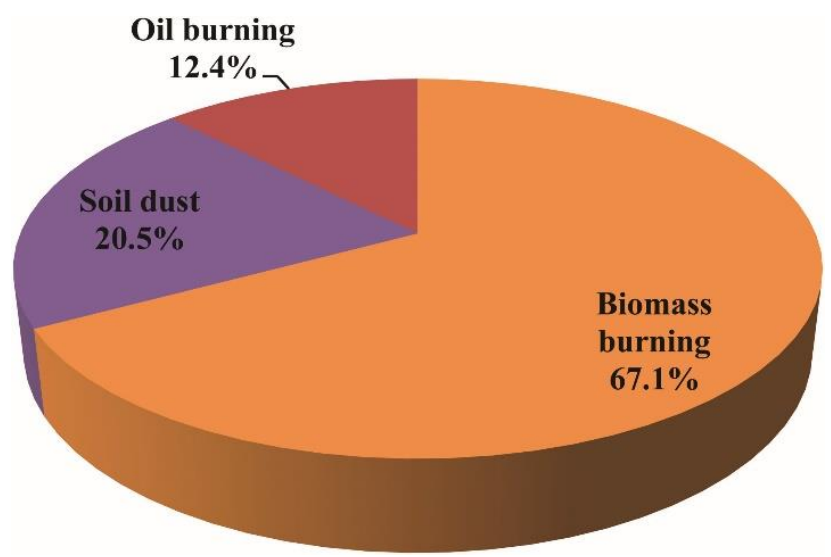

Figure 12. Source contribution for receptor site of Eratyra (S3)

The next source is typical soil dust including natural windblown dust and fugitive dust emissions from agricultural activities. This factor is represented by elements $\mathrm{Al}(80.9 \%), \mathrm{Mg}(72.1 \%), \mathrm{Ca}(64 \%), \mathrm{Mn}(70.3 \%)$, Fe (73.2 \%), Ni (72.4\%), Co (75.7\%), Ba (63.3\%) and Th (92.3\%) which are mainly originated from crustal source (Lopez et al., 2005). Soil dust constitutes about $20.5 \%$ of the PM10 during the whole period with an average of 3.6 $\mu \mathrm{g} \mathrm{m}^{-3}$.

Finally, the third factor is assumed to be the oil combustion for residential heating. This factor was dominated by $\mathrm{V}$ (57.2\%), $\mathrm{Cr}$ (72.9\%), $\mathrm{Zn}(72.6 \%)$, As (72,3\%) and $\mathrm{Cd}(71.2 \%)$. In accordance to literature (Vallius et al., 2005), V originates from oil combustion and it is widely used as a typical marker. The contribution of oil combustion was $12.4 \%$ of PM10 mass on an average of $2.2 \mathrm{\mu g} \mathrm{m}^{-3}$.

\section{Conclusions}

PM10 measurement campaign was conducted throughout one-year period at three receptor sites with different features in Western Macedonia, a region in NW Greece with mining and lignite power operations.

The mean PM10 concentrations in areas proximal and far from mining and power station operations were below the annual limit while the mean annual concentration at receptor site in the centre of industrial zone was equal to the current standard value of $40 \mu \mathrm{g} \mathrm{m}^{-3}$.

Furthermore, the highest PM10 daily values were also recorded at the site in the vicinity of the industrial activities, namely, 46 mean daily values (28.2\%) of 163 samples, exceeded the daily EU limit value.

At all receptor sites, the mean values of $\mathrm{Pb}, \mathrm{V}, \mathrm{As}, \mathrm{Cd}$ and $\mathrm{Ni}$ were lower than the proposed assessment thresholds.

EPA PMF5.0 was used to analyze the elemental data obtained from three sites in the area of interest. At urban- industrial sites, a total of six source types were identified to be important which include: soil dust, coal combustion, road dust, vehicle exhaust, oil combustion and biomass burning. The major contributors of PM10 at the site located proximal to the industrial zone, where urban activities and traffic density take place, were vehicle exhaust (27.2\%), road dust (27.5\%) and soil dust (22.3\%). On the contrary, at the second sampling site, located close to the industrial area with opencast coal mining and lignite combustion activities, major air pollution sources were identified as soil dust (36.8\%) and coal combustion (30.8\%). The major sources at the background site located in a rural residential district not directly influenced by traffic or industrial emissions were biomass burning (67.1\%), soil dust (20.5\%) and oil burning (12.4\%).

Consequently, the final results point out that all three receptors were mostly affected by emission sources in the vicinity of the sampling sites, while no distant transport from industrial activities to the area outside of the industrial axis was observed.

\section{References}

Bruin Y.B., Koistinen K., Yit-Tuomi T., Kephatopoulos S. and Lantunen M. (2006), A review of Source Apportionment Techniquesand Marker substances available for identification of personal exposure, Indoor and Outdoor sources of Chemicals, European Commission, Directorate General, Joint Research Centra, EUR 22349EN.

Bzdusek P.A., Christensen E.R., Lee C.M., Pakadeesusuk U. and Freedman D.C. (2006), PCB congeners and dechlorination in sediments of Lake Hartwell, South Carolina, determined from cores collected in 1987 and 1988, Environmental Science and Technology, 40, 109-119.

Chueinta W., Hopke P.K. and Paatero P. (2000), Investigation of sources of atmospheric aerosol at urban and suburban residential areas in Thailand by positive matrix factorization, Atmospheric Environment, 34, 3319-3329.

Comero S., Capitani L. and Gawlik B. (2009), Positive Matrix Factorisation (PMF) - An Introduction to the Chemometric Evaluation of Environmental Monitoring Data Using PMF, EUR - Scientific and Technical Research Reports, EUR 23946 EN.

Cruz J.M.A., Sarmento S., Almeida M.S., Silva V.A., Alves C., Freitas C.M. and Wolterbeek H. (2015), Association between atmospheric pollutants and hospital admissions in Lisbon, Environmental Science and Pollution Research, 22, 55005510.

Diapouli E., Manousakas M., Vratolis S., Vasilatou V., Maggos Th., Saraga D., Grigoratos Th., Argyropoulos G., Voutsa D., Samara C. and Eleftheriadis K. (2017), Evolution of air pollution source contributions over one decade, derived by PM10 and PM2.5 source apportionment in two metropolitan urban areas in Greece, Atmospheric Environment, 164, 416-430.

DIRECTIVE 2008/50/EC OF THE EUROPEAN PARLIAMENT AND OF THE COUNCIL of 21 May 2008 on ambient air quality and cleaner air for Europe.

Dockery D.W. and Pope III C.A. (1994), Acute respiratory effects of particulate air pollution, Annual Review of Public Health, 15, 107-132. 
EC (1998), Common position No 57/98, 98/C360/04, Official Journal of European Communications C360/99.

EC (1999), Council Directive 83/399/ECC relating to limit values for sulphur dioxide and oxides of nitrogen, particulate matter and lead in ambient air. Official Journal of European Communications L 163/99.

EC, European Commission (2003), Proposal for a directive of the European Parliament and of the Council, relating to arsenic, cadmium, mercury, nickel and polycyclic aromatic hydrocarbons in ambient air. Brussels, 16.7.2003.

Garas S., Triantafyllou A., Zapsis S., Diamantopoulos Ch., Skordas I. and Bartzis J. (2017), PM10 concentrations, trace elements and sources' identification in three representative receptors of Western Macedonia, Greece, Proceedings of the 15th International Conference on Environmental Science and Technology Rhodes, Greece, 31 August to 2 September 2017, CEST2017_01023.

Gupta I., Salunkhe A. and Kumar R. (2012), Source Apportionment of PM10 by Positive Matrix Factorization in Urban Area of Mumbai, India, The cientific World Journal, 2012, 585791, DOI: $10.1100 / 2012 / 585791$.

Houthuijs D. et al. (2001), PM10 and PM2.5 concentrations in Central and Eastern Europe: results from the Cesar study, Atmospheric Environment, 35, 2757-2771.

Huang X.C., Ilhan O. and Namik A.K. (1994), Emissions of trace elements frommotor vehicles: potential marker elements and source compositionprofile, Atmospheric Environment, 28, $1385-1391$.

Izquierdo M. and Querol X. (2012), Leaching behavior of elements from coal combustion fly ash: An overview, International Journal of Coal Geology, 94, 54-66.

Jannsen N.A.H., Van Mansom D.F.M., Van Der Jagt K., Harseema H. and Hoek G. (1997), Mass concentration and elemental composition of airborne particulate matter at street and background locations, Atmospheric Environment, 31(8), 1185-1993.

Kalaitzoglou M., Terzi E. and Samara C. (2004), Patterns and sources of particle-phase aliphatic and olycyclic aromatic hydrocarbons in urban and rural sites of western Greece, Atmospheric Environment, 38, 2545-2560.

Kim H.S., Huh B.J., Hopke K.P., Holsen M.T. and Yi S.M. (2007), Characteristics of the major chemical constituents of PM 2.5 and smog events in Seoul, Korea in 2003 and 2004, Atmospheric Environment, 41(32), 6762-6770.

Lazaridis N., Semb A., Larssen S., Hjellbrekke A.G., Hov Q., Hanssen J.E., Schang J. and Torseth K. (2002), Measurements of particulate matter within the framework of the European Monitoring and Evaluation Programme (EMEP) I. First Results, Science of the Total Environment, 285, 209-235.

Lee E., Chan K.C. and Paatero P. (1999), Application of positive matrix factorization in source apportionment of particulate pollutants in Hong Kong, Atmospheric Environment, 33(19), 3201-3212.

Lee J.H., Yoshida Y., Turpin B.J., Hopke P.K., Poirot P.J., Lioy P.J. and Oxley J.C. (2002), Identification of sources contributing to mid-Atlantic regional aerosol, Journal of the Air and Waste Management Association, 52, 1186-1205.

Lim J.M., Lee J.H., Moon J.H. Chung Y.S. and Kim K.H. (2010), Source apportionment of PM10 at a small industrial area using Positive Matrix Factorization, Atmospheric Research, 95, 88-100.

Lopez J.M., Callen M.S., Murillo R., Garcia T., Navarro M.V., de la Cruz M.T. and Mastral A.M. (2005), Levels of selected metals in ambient air PM10 in an urban site of Zaragoza (Spain), Environmental Research, 99, 58-67.

Manousakas M., Diapouli E., Papaefthymiou H., Migliori A., Karydas G.A., Padilla-Alvarez R., Bogovac M., Kaiser B.R., Jaksic M., Bogdanovic-Radovic I. and Eleftheriadis K. (2015), Source apportionment by PMF on elemental concentrations obtained by PIXE analysis of PM10 samples collected at the vicinity of lignite power plants and mines in Megalopolis, Greece, Nuclear Instruments and Methods in Physics Research, B349, 114-124.

Matthaios V.N., Triantafyllou A.G. and Albanis T.A. (2013), Performance and verification of a downscaling approach for meteorology and land use, using a mesoscale model in a complex terrain industrial area in Greece, 13th International Conference on Environmental Science and Technology Athens, Greece, 5-7 September 2013, Proceedings: CEST2013_0513.

Matthaios V.N., Triantafyllou A.G., Albanis T.A., Sakkas V. and Garas S. (2018), Performance and evaluation of a coupled prognostic model TAPM over a mountainous complex terrain industrial area, Theoretical and Applied Climatology, 132(34), 885-903.

Monaci F. and Bagagli R. (1987), Barium and other trace metals as indicators of vehicle emissions, Water, Air, and Soil Pollution, 100, 89-98.

Morishita M., Keeler G.J., Wagner J.G. and Harkema J.R. (2006), Source identification of ambient PM2.5 during summer inhalation exposure studies in Detroit, MI, Atmospheric Environment, 40, 3823-3834.

Paatero P. and Tapper U. (1993), Analysis of different modes of factor analysis as least squares fit problems, Chemometrics and Intelligent Laboratory Systems, 18, 183-194.

Paatero P. and Tapper U. (1994), Positive matrix factorization: a non-negative factor model with optimal utilization of error estimates of data values, Environmetrics, 5, 111-126.

Pakkanen T., Loukkola K., Kohonen C., Aurela M., Mäkelä T., Hillamo R., Aarnio P., Koskentalo T., Kousa A. and Maenhaut W. (2001), Sources and chemical composition of atmospheric fine and coarse particles in the Helsinki area, Atmospheric Environment, 35, 5381-5391.

Petaloti C., Triantafyllou A., Kouimtzis T. and Samara C. (2006), Trace elements in atmospheric particulate matter over a coal burning power production area of Western Macedonia, Greece, Chemosphere, 65, 2233-2243.

Polissar A.V., Hopke P.K., Paatero P., Malm W.C. and Sisler J.F. (1998), Atmospheric aerosol over Alaska-2, Elemental composition and sources, Journal of Geophysical Research, 103(D15), 19045-19057.

Querol X., Alastuey A., Rosa J.D.L., Sánchez-de-la-campa A., Plana F. and Ruiz C.R. (2002), Source apportionment analysis of atmospheric particulates in an industrialised urban site in southwestern Spain, Atmospheric Environment, 36, 31133125.

Samara C. (2005), Chemical mass balance source apportionment of TSP in a lignite-burning area of Western Macedonia, Greece, Atmospheric Environment, 39, 6430-6443.

Samara C., Argyropoulos G., Grigoratos Th., Kouras A., Manoli E., Andreadou S., Pavloudakis F. and Sahanidis Ch. (2018), 
Chemical characterization and receptor modeling of PM10 in the surroundings of the opencast lignite mines of Western Macedonia, Greece, Environmental Science and Pollution Research, 25, 12206-12221.

Santoso M., Hopke P.K., Hidayat A. and Dwiana D.L. (2008), Sources identification of the atmospheric aerosol at urban and suburban sites in Indonesia by positive matrix factorization, Science of the Total Environment, 97, 229-237.

Schauer J.J., Lough G.J., Shafer M.M., Christensen W.F., Arndt M.F., DeMinter J.T. and Park J.-S. (2006), Characterization of Metals Emitted from Motor Vehicles, vol. 133, Health Effects Institute, Boston, MA, U.S.A. Research Report.

Schwartz J., Dockery D.W. and Neas L.M. (1996), Is daily mortality associated specifically with fine particles? Journal of Air and Waste Management Association, 46, 927-939.

Smichowski P., Gómez D., Frazzoli C. and Caroli S. (2008), Trafficrelated elements in airborne particulate matter, Applied Spectroscopy Reviews, 43, 23-49.

Tolis E.I., Saraga D.E., Ammari G.A., Gougoulas T., Papaioannou C.C., Sarioglou A.K., Kougioumtzidis E., Sfetsos A. and Bartzis J.G. (2014), Chemical characterization of particulate matter (PM) and source apportionment study during winter and summer period for the city of Kozani, Greece, Central European Journal of Chemistry, 12(6), 643-651.

Triantafyllou A.G. (2001), $\mathrm{PM}_{10}$ pollution episodes as a function of synoptic climatology in a mountainous industrial area, Environmental Pollution, 112, 491-500.

Triantafyllou A.G., Garas S., Zoras S., Evagelopoulos V. and Asvesta A. (2007), Particulate matter concentrations and elemental analysis in four cities of northwestern Greece, Fresenius Environmental Bulletin, 16(5), 508-516.

Triantafyllou A.G., Helmis C.G., Asimakopoulos D.N. and Soilemes A.T. (1995), Boundary layer evolution over large and broad mountain basin, Theoretical and Applied Climatology, 52(2), 19-25.

Triantafyllou A.G., Zoras S. and Evagelopoulos V. (2006), Particulate Matter Over A Seven Year Period in urban and rural areas within, proximal and far from mining and power station operations in Greece, Environmental Monitoring and Assessment, 122, 41-60.

Uberoi M. and Shadman F. (1991), High-temperature removal of cadmium compounds using solid sorbents, Environmental Science and Technology, 25, 1285-1289.

USEPA (1999), SPECIATE: EPA's repository of total organic compound and particulate matter speciated profiles for a variety of sources for use in source apportionment studies, US Environmental Protection Agency, Office of Air Quality Planning and Standards, Research Triangle Park, NC.

Vallius M., Janssen N.A.H., Heirich J., Hoek G., Ruuskanen J., Cyrys J.,Grieken R.V., Hartog J.J., Kreyling W.G. and Pekkanen J. (2005), Sources andelemental composition of ambient PM2.5 in three European cities, Science of the Total Environment, 337, 147-162.

Viana M., Kuhlbusch T.A.J., Querol X., Alastuey A., Harrison R.M., Hopke P.K.,Winiwarter W., Vallius M., Szidat S., Prévôt A.S.H., Hueglin C., Bloemen H.,Wåhlin P., Vecchi R., Miranda A.I., Kasper-Giebl A., Maenhaut W. and Hitzenberger R. (2008), Source apportionment of particulate matter in Europe: $A$ review of methods and results, Aerosol Science, 39, 827-849.
Voutsa D., Samara C., Kouimtzis, Th. and Ochensenkühn K. (2002), Elemental composition of airborne particulate matter in multi-impacted urban area of Thessaloniki, Greece, Atmospheric Environment, 36, 4453-4462.

Watson G.J. (2004), Desert Research Institute, Protocol for Applying and Validating the CMB Model for PM 2.5 and VOC, US Environmental Protection Agency, Air Quality Modeling Group.

WHO (2000), Air Quality Guidelines for Europe. WHO Reginal Publications EurSer No 91, Regional Office for Europe, Copenhagen, Denmark. 